Giddens, Anthony: Yhteiskuntateorian keskeisiä ongelmia. Toiminnan, rakenteen ja ristiriidan käsitteet yhteiskunta-analyysissä. Suom. Pasi Andersson ja Ilkka Heiskanen. Otava. Helsinki 1984. $423 \mathrm{~s}$.

Anthony Giddensin pyrkimyksenä on luoda uusi yhteiskuntateoria, joka sulkee sisäänsä perinteisesti ymmärretyn sosiologian, yhteiskuntafilosofian ja historian. Hänen tarkastelutapansa ei ole kuitenkaan poikki- tai monitieteellinen, vaan sosiologinen sanan laajassa merkityksessä. Pyrkimyksiltään Giddens muistuttaa Frankfurtin koulun (Horkheimer, Adorno, Marcuse ym.) kriittistä teoriaa ja onkin outoa, että Giddens tyytyy niin niukasti viittaamaan näihin edeltäjiinsä.

Millä tavalla Giddens toteuttaa ohjelmaansa uuden yhteiskuntateorian luomiseksi? Nyt julkaistu kirja on jatkoa Giddensin aiemmille teoksille ja samalla ennakointia tulevista. 1 Kirja on pikemminkin koonta aiemmista erillisistä artikkeleista kuin yhtenäinen teos. Kirjan seitsemän lukua voidaan lukea erillisinä jaksoina, vaikka niitä yhdistää pyrkimys kahden peruskäsitteen dualismin voittamiseen. Yhteiskuntateoriassa "rakenne" ja "toiminta" ovat usein keskenään antinomisia käsitteitä, jotka sisäiseltä logiikaltaan hylkivät toisiaan. Giddens pyrkii osoittamaan omassa rakenteistumisen teoriassaan rakenteen ja toiminnan ristiriitaisen vuorovaikutuksen. Jotta rakenne ja toiminta voitaisiin teoreettisesti yhdistää, tarvitaan ainakin seuraavat elementit: ensinnäkin inhimillistä toimijaa (subjektia) koskeva teoria, toiseksi tarvitaan tulkitseva kuvaus toiminnan olosuhteista ja seurauksista ja kolmanneksi tarvitaan tulkinta siitä, mitä rakenne (struktuuri) näi- hin olosuhteisiin ja seurauksiin kytkeytyvänä käsitteenä todella merkitsee.

Matkalla tällaiseen teoriaan Giddens käy läpi mittavan määrän materiaalia. Yhteiskuntateorian, filosofian, semiotiikan, psykoanalyysin, antropologian ym. tieteenalojen ja tutkimusalojen piiristä poimitaan esiin nimiä, joita ei välttämättä aina ole totuttu liittämään toisiinsa: Althusser, Barthes, Comte, Derrida, Durkheim, Freud, Goffman, Habermas, Husserl, Lavan, Lévi- Strauss, Lukács, Marx, Mead, Merton, Parsons, Saussure, Schutz, Weber ja Wittgenstein. Näin laajan ja tässä poimin vain osan kiinnostavista nimistä - alueen hallitseminen vaatii veronsa: useiden teorioiden kritiikkiin siirrytään varsin nopeasti jo ennen näiden toerioiden huolellista tarkastelua. Toisaalta Giddensin käyttämä toereetikkojen galleria ei ole vahakabinetti vaan muistuttaa enemmän jalkapallokenttää, jossa eri teoreetikot potkivat "rakenteen" ja "toiminnan" palloa - ja välillä myös toisiaan. Käsittelyssä Giddens joutuu usein tekemään viittauksia tuleviin teoksiinsa, joissa asiaa käsitellään tarkemmin.

Aloitusluvussa, joka on ehkä kirjan mukaansatempaavin, Giddens tarkastelee strukturalismia ja subjektin asemaa koskevaa teoriaa. "Strukturalismi" on "funktionalismin" (lainausmerkkien käyttö viittaa siihen, että kyseiset nimet ovat melko sopimuksenvaraisia eivätkä kykene kuvaamaan täsmällisesti rajautuvaa teorioiden kenttää) ohella toinen keskeisistä laajoista yhteiskuntateorioista viimeisten kolmen- neljänkymmenen vuoden aikana. Molempien esi-isänä voidaan Giddensin mukaan pitää Emile Durkheimia. "Strukturalismin" ansiona Giddens pitää 
sen nostamien kysymysten keskeisyyttä (eroavuuden kautta tapahtuva järjestyminen, aikadimension keskeisyys, antihistorisismi, kokonaisuuden painottaminen, pyrkimys subjekti/objekti dualismin ylittämiseen. Humanismin kritiikki- "teoreettinen antihumanismi", kulttuurituotteiden tuottamisprosessin korostaminen).

Myöhemmissä luvuissa Giddens kehittelee omaa toimijana toimimisen teoriaansa (luvut 2 ja 3) sekä tekee yksityiskohtaisempia tutkimuksia keskeisiin käsitteisiin (ristiriita, valta, historiallinen materialismi, ideologia ja tietoisuus, aika, paikka ja yhteiskunnallinen muutos). Metodologisesti kiinnostavan väitteen tieteen ja arkitietoisuuden välisestä suhteesta Giddens muotoilee seuraavasti: "jokainen yhteiskunnalliseen toimintaan osallistuva toimija omaa huomattavassa määrin tietoa sen yhteiskunnan uusintamisen olosuhteista, jonka jäsen hän on." (ko. teos, 24). Näin esitettynä, väite voi tuntua triviaalilta, mutta se sisältää monia ongelmallisia kysymyksiä. Giddens jakaa yhteiskuntaa koskevan tiedon kahteen alueeseen, tiedostamattomaan, joka käsittää ne säännöt, joita noudatamme toiminnassamme, vaikka emme tiedä niitä noudattavamme ja diskursiivinen tieto, jonka kykenemme ilmaisemaan käsityksemme siitä, mitä sääntöjä noudatamme tai miten yhteiskunta toimii. Ensinmainittua voidaan kutsua myös käytännön tietoisuudeksi. Giddensin mukaan sekä 'strukturalismin" että "funktionalismin" perusheikkous on siinä, että ne eivät ota vakavasti yhteiskunnan jäsenten keskinäistä tietoa yhteiskunnasta. Yhteiskuntateorian kehittely edellyttää tämän keskinäisen tiedon hyväksymistä sellaisenaan osaksi yhteiskunnallisen tietämyksen lähdettä. Sosiologisen tutkimuksen on kuitenkin asetettava kyseinen tietoisuus osaksi kokonaisuutta.

Viimeisessä luvussa Giddens tarkastelee yhteiskuntateorian tulevaisuudennäkymiä. Hän toteaa sosiologian "ortodoksisen yksimielisyyden" ajan olevan takana päin, mutta pyrkimyksenä on kehittää sosiologiaa siten, että erilaiset ainekset kyettäisiin kokoamaan uuden, entistä laajemman teorian siipien alle. Reaktiot "sosiologian kriisiin" ovat olleet joko pettymystä siihen, että "suurta teoriaa" ei ole kyetty yksimielisesti luomaan tai sitten on pyritty palaamaan "dogmatismiin" tavoitteena saavuttaa edes jonkinlainen varmuus lähtökohdasta. (Metodologinen viisastelu on jätetty filosofeille!) On ollut myös niitä, jotka ovat iloinneet moninaisuuden, pluralismin voittokulusta sosiologisessa teorianmuodostuksessa. Giddens ei hyväksy näitä reaktioita "Baabelin tornin tilanteeseen' ja ehdottaa kunnianhimoisesti "uutta systemaattista teorian rakentamista", (357). Sosiologian ei tule hävetä tilaansa. Sillä on pitkät perinteet, sen juuret eivät ole vain Comtessa. Suhteessa luonnontieteisiin sosiologialla ei ole alamaisuuden tunnetta; on vain suhteuttava sosiologian kehitys yhteiskunnalliseen muutokseen.

Teoksen käännös on ollut suururakka, josta Pasi Andersson ja Ilkka Heiskanen ovat selviytyneet hyvin. Tekstin vaikealukuisuus ja raskaus on useimmiten peräisin itse asian moniselkoisuudesta. Kääntäjät ovat pyrkineet kehittämään yhteiskuntateorian ja filosofian suomenkielistä sanastoa kääntämällä useita sivistyssanoja suomenkieliseen asuun. Osa on onnistuneita, mutta joidenkin osalta tilanne ei tunnu luontevalta. Vaikka esimerkiksi Saussuren erottelun signifiant/signifié kääntäminen sanaparilla merkityksellistäjä/merkityksellistettävä on varmaan tarkempi kuin termien ilmaisu/sisältö termien käyttö, johon Eero
Tarasti on päätynyt Greimas -käännöksessään ${ }^{2}$ se ei lukijan kannalta ole selkeä (hankaluus on ilmeinen kyllä myös ranskankielessä tai englanninkielessä).

Samoin filosofisessa kirjallisuudessa jo vakiintuneen ilmaisun referentti korvaaminen suomenkielisellä kohdeviite-termillä tuntuu oudolta. Kysymys voi tietysti olla vain tottumuksesta.

Kaiken kaikkiaan: Giddensin kirja on melkoista pukkihyppelyä yhteiskuntateorian moninaisuudessa, mutta juuri sellaisenaan virkistävä. Suureen synteesiin on vielä monta hyppyä.

\section{Pekka Kalli}

\section{Viitteet}

1. Giddens on julkaissut aikaisemmin seuraavat teokset, jotka ovat myös suomalaisen lukijakunnan piirissä tunnettuja: Capitalism and Modern Social Theory (Cambridge: University press 1971)

New Rules of Sosiological Method (London: Hutchinson 1976)

Studies in Social and Political Theory (London: Hutchinson 1977)

2. Greimas, A.J.: Strukturaalista semantiikkaa. Suom. Eero Tárasti. Gaudeamus. Helsinki 1980 